\title{
Strategies of Engagement: Lessons from the Critical Examination of Collaboration and Conflict in an Interorganizational Domain ${ }^{*}$
}

\author{
Cynthia Hardy and Nelson Phillips \\ Faculty of Management \\ McGill University \\ 1001 Sherbrooke West \\ Montreal, Canada, H3A 1 G5 \\ Tel: (514) 3984020
}

Published in Organization Science9(2), 217-230, 1998.

* The authors wish to acknowledge the financial support of the Social Sciences \& Humanities Research Council of Canada, les Fonds pour la Formation des Chercheurs et l'Aide à la Recherche of Quebec, and McGill University in carrying out this research. 


\section{Strategies of Engagement: Lessons from the Critical Examination of Collaboration and Conflict in an Interorganizational Domain}

Many writers advocate interorganizational collaboration as a solution to a range of organizational and intersectoral problems.Accordingly, they often concentrate on its functional aspects. We argue that collaboration deserves a more critical examination, particularly when the interests of stakeholders conflict and the balance of power between them is unequal. Using examples from a study of the UK refugee system, we argue that collaboration is only one of several possible strategies of engagement used by organizations as they try to manage the interorganizational domain in which they operate. In this paper, we discuss four such strategies: colloboration; compliance; contention; contestation. By examining the stakeholders in the domain and asking who has formal authority, who controls key resources, and who is able to discursively manage legitimacy, researchers are in a stronger position to evaluate both the benefits and costs of these strategies and to differentiate more clearly between strategies that are truly collaborative and strategies that are not. In other words, we hope to demonstrate that collaboration between organizations is not necessarily "good"; conflict is not necessarily "bad"; and surface dynamics are not necessarily an accurate representation of what is going on beneath.

Keywords: interorganizational collaboration; conflict; interorganizational domain; power; refugee systems 


\section{Introduction}

Collaborative strategies have been attracting increasing attention as a means to address problems that range from deregulation, to globalization, to sustainable development (e.g., Astley, 1984; Bresser \& Harl, 1986; Harrigan, 1985; Carney, 1987; Bresser, 1988; Kanter, 1990). Writers have argued that collaboration across different economic sectors can bring together business, government, and non-government organizations to tackle important social and environmental issues (e.g., Gray, 1989; Waddock, 1989; Westley \& Vredenburg, 1991). Through the pooling of expertise and resources, collaboration can solve intractable problems (Trist, 1983) in ways that confrontation or competition cannot. Accordingly, much of the literature on interorganizational relations has focused on the virtues of collaboration. It is considered to be beneficial for participants (e.g., Alter, 1990; Knoke, 1990; Nathan \& Mitroff, 1991; Alter \& Hage, 1993) because "parties who see different aspects of a problem can constructively explore their differences and search for solutions that go beyond their own limited vision of what is possible” (Gray, 1989: 5). In addition, those outside the collaboration also stand to profit through the opening up of "access and agendas to wider participation” (Gray, 1989: 120; also Nathan \& Mitroff, 1991; Alter \& Hage, 1993).

It has been noted, however, that much of the research in this area adopts a functionalist rather than a critical perspective (e.g., Warren et al., 1974; Hazen, 1994). Consequently, collaboration is often seen as a means of reducing uncertainty, acquiring resources and solving problems; and it is often assumed that stakeholders collaborate voluntarily, sharing common goals and equal power. Furthermore, as Knights et al. (1993) have noted, issues such as exploitation, repression, unfairness and asymmetrical power relations, which have preoccupied critical theorists, are often neglected. We suggest that these issues are crucial to an understanding of collaboration, particularly when partners have different goals, values and beliefs (Waddock, 1989) and when the distribution of power between them is unequal (Gray \& Hay, 1986). In such situations, collaboration may not be intended for the good of all participants or for stakeholders outside the collaboration, but to protect specific organizational interests. For example, more powerful stakeholders may force collaboration on weaker players to control them; or they may cooperate with other powerful allies to prevent opponents from reconstituting the domain (e.g., Warren et al., 1974; Rose \& Black, 1985; Hasenfeld \& Chesler, 1989). In other words, collaboration may mask moves by powerful organizations to protect their privileged positions and disadvantage less powerful stakeholders: those who collaborate are coopted; those who do not are excluded.

This paper argues that we need to cast a more critical eye over collaboration, especially in the event of conflicting goals and unequal power. To do so, we make two recommendations. First, we need to extend the level of analysis beyond a particular collaboration to include the interorganizational domain in which the interaction takes place. Second, we need to view collaboration as simply one of a number of strategies of engagement used by stakeholders to change or maintain the parameters of the interorganizational domain in which they operate. In this way, we can examine conflict as well as collaboration and assess the implications of both for different stakeholders in the domain (also see Gricar \& Brown, 1981).

To explore the potential of such an analysis, we provide examples from the UK refugee system, an interorganizational domain consisting of government and nongovernment stakeholders. While the UK refugee system involves public sector organizations, it is nonetheless a particularly fruitful site in which to observe the dynamics of an interorganizational domain 
because stakeholders have conflicting goals and power is distributed unequally among them. As a result, the UK refugee system represents a "transparent" example (Eisenhardt, 1989) in which theoretical issues can be explored and implications drawn for other sectors.

The remainder of this paper proceeds as follows. First, we provide a theoretical discussion of interorganizational domains. Next we introduce readers to the UK refugee system and to five organizations that play important roles within it. Then we differentiate four strategies of engagement. Finally, we draw some important lessons for research and practice. In particular, we argue that researchers must dig below the surface when examining apparent cooperation to ensure that asymmetrical power relations are not driving apparently cooperative interorganizational relationships, thereby reducing the likelihood of synergy and creativity. We also demonstrate that conflict may be concomitant with transformational change in the domain because it upsets existing power relationships. Thus, the creative and synergistic outcomes, which many writers associate with collaboration, may also follow from conflictual interorganizational relationships.

\section{Interorganizational Domains: A Critical Perspective}

While interorganizational relationships have been examined from a number of different perspectives, this paper draws primarily on the body of literature on interorganizational domains (e.g., Trist, 1983; McCann, 1983; Brown, 1983; Gray, 1989; Westley \& Vredenburg, 1991). Interorganizational domains emerge as different organizations perceive themselves to be connected to common issues. They are not objective, predetermined structures, but processes of social construction (McGuire, 1988) and meaning creation (Altheide, 1988), wherein social order is negotiated (Strauss et al., 1963; Gray, 1989; Nathan \& Mitroff, 1991).

Domains are cognitive as well as organizational structures ... one can only too easily fall into the trap of thinking of them as objectively given, quasi-permanent fixtures in the social fabric rather than ways we have chosen to construe various facets of it (Trist, 1983: 273).

As individuals come to share a vision of the issues and participants that constitute the domain, they become stakeholders. This shared appreciation creates an identity for the domain, and mutually agreed upon directions and boundaries, which may be perceived and experienced as a permanent structure (Trist, 1983). In this way, the development of an interorganizational domain is a process of social construction that enables stakeholders to communicate, be identified and legitimated, and acknowledge the problems they face.

The literature on interorganizational domains and negotiated order theory often fails to deal adequately with the role of power (see Hardy, 1994; also Benson, 1977, 1978; Day \& Day, 1977, 1978; O'Toole \& O'Toole, 1981 of negotiated order theory). Although writers have acknowledged that power is important in the emergence of interorganizational domains, they have not always offered very convincing explanations concerning why dominant groups would share power with other groups in a collaborative venture. If organizations have a stake in the domain, and the domain is socially constructed, then it is in the interests of each stakeholder to do everything possible to ensure that the domain is constructed in the way that affords it the most advantage. Since the ability to participate in social construction - the ability to create meaning

— is differentially distributed between actors (e.g., Berger \& Luckman, 1966; Pettigrew, 1979; O’Toole \& O’Toole, 1981; Smircich \& Morgan, 1982; Hardy, 1985a,b; Frost, 1987; Altheide, 1988), one might expect those stakeholders with more power to use it to shape the 
interorganizational domain to their advantage. This might lead them to share power in the case of convergent goals, but they are unlikely to do so when goals conflict.

\section{Power in Interorganizational Domains}

Clearly then, the dynamics of power are a central aspect of the constitution of organizational domains. A variety of different frameworks and conceptualizations of power exist (e.g. Lukes, 1974; Frost, 1987; Clegg, 1989; Bourdieu, 1993; Hardy, 1994; Hardy \& Clegg, 1996) and it is not our purpose to explore them here. Instead, we present a simplified framework that highlights three aspects of power - formal authority, the control of critical resources, and discursive legitimacy — which are particularly useful in making sense of dynamics in interorganizational domains.

Formal authority refers to the recognized, legitimate right to make a decision (see French \& Raven, 1968; Astley \& Sachdeva, 1984). In an interorganizational domain, such power might rest with one particular organization, such as the government; it might be shared between organizations as in a joint venture; it may rest with a convenor; or it may be dispersed. In the refugee system, formal authority lies with the government - the only actor with the legitimate authority to determine refugee status (Cohen, 1994). Scarce or critical resources (e.g., Hickson et al., 1971; Pettigrew, 1973; Pfeffer \& Salancik, 1978; Pfeffer, 1981; Astley \& Sachdeva, 1984) also play an important role in interorganizational domains. When one organization or group relies on another for a critical resource, such as expertise, money, equipment, information, etc., the dependent organization is at a power disadvantage. In some domains, funding or other resources may be concentrated in the hands of one participant, whereas in others these resources may be widely dispersed. Third, some organizations may be able to influence the process of social construction that forms the domain, even though they possess neither formal authority nor critical resources, but because they have discursive legitimacy (Mumby \& Stohl, 1991; Fairclough, 1992; Parker, 1992; Thompson, 1990; also see Phillips \& Hardy, 1997). Such actors are understood to be speaking legitimately for issues and organizations affected by the domain (see Phillips \& Brown, 1993). For example, environmental groups such as Greenpeace can affect public understanding, attract media attention and pressure the government, because they are understood to be speaking on behalf of the environment. Discursive legitimacy may afford such organizations more influence than resource-rich corporations or formal decision-makers whose self interest is more obvious.

Combined, these three aspects of power provide a framework for analyzing the dynamics of interorganizational domains. Thus, when one organization is "dependent" on another, we should not simply assume that a resource-dependency relationship binds the two; we must also consider who has formal authority and who has discursive legitimacy. Different patterns of power distribution have profound implications for the way in which the domain evolves.

Clearly, then, the actors with greater access to authority, resources, and discursive legitimacy will have the best chance of success in influencing the domain. Sometimes, dominant stakeholders may want to ensure that the domain does not change. For example, Hall \& SpencerHall (1982) point out that changes in the social order are unlikely to occur when power is concentrated in the hands of dominant groups. In other cases, dominant stakeholders may want to initiate change - but in a form that suits them. Levy (1982: 293) has noted the "self-serving strategies" of individuals and interest groups who define and control the context in which negotiations occur. The question is, how do stakeholders use their power and how does it affect interactions between them and other organizations in the domain? There are two primary ways in 
which powerful stakeholders can influence the domain: by (re)defining the issue around which the domain forms; by influencing the participation of other stakeholders.

First, the issue or "problem" around which a domain forms is not predetermined, waiting to be "discovered", but is created as a result of interorganizational interactions. As Blumer (1971) has pointed out, social problems do not exist in any objective sense - they are "named" as a result of the collective, discursive practices that create meaning for them. This process is, in turn, influenced by the interests and actions of different players with different stakes in the problem. The way in which a problem is defined has important implications for the subsequent direction of the domain; it places limits on the potential nature and outcome of interactions and plays an important role in determining who has a legitimate case for membership in the collaboration (Gray, 1989). Thus, the identification and legitimation of strategic issues and problems is an important mechanism through which power is exercised (Dutton \& Duncan, 1987). In this situation, collaboration might be used to defend against incursions by new stakeholders who want to redefine the domain in a way that threatens existing patterns of advantage. Warren et al. (1974; also Rose \& Black, 1985) document just such a situation in the mental health community when an organization challenged existing definitions of mental health problems as a "disease" and, instead, attributed many of them to social problems. The new problem definition required a very different solution, one in which mental health patients were empowered. Conflict between the two sides ensued as the domain's powerholders collaborated to try and exclude the newcomer and marginalize its views. It is worth noting that in this situation, collaboration characterized a bid to maintain the status quo while conflict was associated with new approaches to mental health care that many observers might find "enlightened" and "progressive".

Second, power can be used to influence decisions concerning the inclusion and exclusion of stakeholders. Writers argue that all "legitimate" stakeholders should be included (Gray, 1985). Legitimacy, however, is not an objective state, but one based on power (Frost, 1987) and created through the management of meaning (Pettigrew, 1979; Smircich \& Morgan, 1982).

Consequently, individuals and organizations require sufficient power to demonstrate that they have a "legitimate" right to participate. For example, Gray and Hay (1986) describe the process by which certain groups were excluded from the National Coal Policy Project (NCPP) - a collaborative project in the US coal industry. The convenors chose not to invite members of the United Mine Workers (UMW) to participate because of their desire to "limit the diversity of viewpoints" (1986: 105). Clearly, inviting the UMW would have jeopardized the agenda of other powerful stakeholders. The convenors deliberated long and hard over whom to include, and their eventual decisions were often influenced by considerations of the power of stakeholders within the domain. These decisions effectively restricted some stakeholders from participating even though they — and the domain — might be affected by the outcomes of the collaboration (Gray \& Hay, 1986). The identification and legitimation of stakeholders is not, then, determined by any objective "right" to participate but is influenced by whether dominant stakeholders allow less powerful stakeholders to participate which, in turn, is related to the former's vested interests. Thus, collaboration is important for who is excluded as much as who is included.

In summary, the social nature of an interorganizational domain provides an opportunity for more powerful stakeholders to influence its definition and development in ways that afford them the most advantage. These power dynamics may mean that interactions which appear to be collaborative, in fact, mask defensive manoeuvres to maintain the status quo; and that conflict 
signals an attempt to redefine the domain in a way that takes into account the needs of stakeholders that have been previously ignored. To explore these issues, we must move beyond a functional approach towards collaboration and consider it to be one of a number of strategies of engagement used by actors to (re)define the domain; and we must move past the focus on collaboration to consider other such strategies, including conflict.

\section{The UK Refugee System ${ }^{1}$}

The 1948 United Nations (UN) Universal Declaration of Human Rights asserts that individuals have the right to seek asylum from persecution in other countries. The UN defines refugees as people who have left their own country because of a well-founded fear of persecution for such reasons as race, religion, nationality, and political opinion. The UK refugee system represents an interorganizational domain comprising government, nongovernment (NGO) and refugee organizations that are involved in determining the status of individuals claiming asylum and in assisting in the settlement of those individuals granted asylum. ${ }^{2}$ We examine five organizations in more detail: the government and, within it, the Immigration and Nationality Department; the Refugee Legal Centre and the British Refugee Council, both NGOs; the Community Development Team, part of the British Refugee Council; and the Refugee Forum, a refugee organization.

\section{The Government}

The government, especially the Home Office and the Immigration and Nationality Department, plays a central role in the UK refugee system. The government drafts and passes the legislation that specifies determination procedures and defines the rights of refugees. In 1991, the government introduced the Asylum and Immigration Appeals Bill which defined refugee rights for the first time and specified new procedures to speed up the processing of applications. The government withdrew the Bill during the 1992 election, but passed a similar version in 1993.

The Immigration and Nationality Department implements government policy on immigration and nationality which, in 1991/2, included allowing "genuine visitors" to enter the UK and restricting "severely the numbers" who did not fall into this category (Home Office, 1991/2: iii). The Department's Immigration Service admits and detains asylum-seekers; while the Asylum Division determines whether asylum-seekers are refugees. The latter was a small unit of less than 120 civil servants until 1991; numbers then increased to 460 within the following year to deal with the growing number of asylum applications (Home Office, 1991/2).

While the central player in determination, the Home Office plays a lesser role in settlement. It provides some funding but so, too, do a variety of other parts of the UK government, through race equity, training, and employment and other initiatives. Local (municipal) governments also play an active role by providing housing, and the London Borough Grants Committee (part of London's municipal government) has been an important source of funding for settlement services, along with a panoply of private charities and trusts.

\section{The British Refugee Council}

The British Refugee Council is a government-funded charity (about 60 percent of a budget of some $£ 5$ million comes from the government) that employs around 200 people to give practical help to refugees and to promote refugee rights in the UK and abroad. It is an umbrella organization for over 100 nongovernment organizations, including well known charities like Oxfam and Save the Children Fund. Approximately one third of its members and its Executive Committee are refugee community organizations. The British Refugee Council is an active lobby group: it was a founding member of the Asylum Rights Campaign, a consortium of NGOs, 
churches, and refugee community organizations, set up in 1991 "to try to prevent the [government's new] proposals from becoming law” (Exile, 1991:1). The Council also actively lobbies for a national settlement policy, in which a centrally coordinated approach to settlement would provide clearly defined services to refugees, although so far to no avail.

\section{The Community Development Team}

The majority of the Council's employees are responsible for providing services to refugees. The Community Development Team was created in 1989 as part of a new initiative to help develop and organize the refugee community. It consists of a team leader and 5 community workers. In 1991, the Team worked with around 70 refugee community organizations on management and governance, fundraising, and training.

The Community Development Team works with numerous other organizations in addition to refugee community organizations. The Team leader works with the Voluntary Sector Forum, which deals with the London Borough Grants Committee - a major funder of refugee community organizations; the Churches’ Working Party for Refugees; as well as borough (municipal) councils in London. The Team helps to set up networks of refugee community organizations, nongovernment organizations, and local authority council workers in several London boroughs. It also works with a number of charitable trusts for fundraising purposes. In 1991, it co-organized a conference on Grantmaking: Charitable Trusts and Refugee Community Organizations which brought together 31 refugee organizations and 20 trusts, foundations and charities.

\section{The Refugee Legal Centre}

The Refugee Legal Centre was initially set up by the government in 1976 as the Refugee Unit, part of a larger, government-funded organization called the UK Immigrant Advisory Service (UKIAS). In April 1991, following the increase in the size of the Asylum Division, the government proposed a parallel increase in the number of caseworkers in the Refugee Unit, while still part of UKIAS. The government also announced plans to end legal aid to refugee claimants and to make the Refugee Unit the sole provider of free legal representation — thereby preventing asylum-seekers from using private solicitors unless they were able to pay for their services. Following widespread criticism, this plan was dropped. In 1992, at the instigation of the government, the Refugee Legal Centre was separated from UKIAS and established as an organization in its own right. In 1993, the Refugee Legal Centre had 45 case workers, up from 15 in 1990, and 88 percent of its budget was government-funded. Its mandate is to provide free, independent legal representation and advice to asylum-seekers during the determination process.

While case workers from other nongovernment organizations and private lawyers also represent refugee claimants, the vast majority of cases are handled by the Refugee Legal Centre. It is also the only nongovernment organization to receive case referrals from the Home Office. In most asylum cases, then, a case worker from the Refugee Legal Centre represents the asylumseeker, while a civil servant from the government's Asylum Division determines the status of that individual. In the event of an appeal of a decision not to grant asylum, the Refugee Legal Centre case worker challenges the Asylum Division's decision directly during the adjudication process.

\section{The Refugee Forum}

Refugees represent the "output constituency" - those affected by the decisions taken in the domain (Warren et al., 1974). They are typically the most powerless of the three groups (Benard, 1986); often traumatized, alone, unorganized, penniless, and unable to speak English. 
Even when refugees organize, these refugee community organizations tend to be small, often employing only a handful of people, and under-resourced, living hand-to-mouth on small grants from municipal governments and charitable trusts (see Salinas et al., 1987; Majika, 1991). One such organization is the Refugee Forum, an umbrella association comprised of other refugee community organizations.

The Refugee Forum, which is neither a charity nor government funded, is an umbrella group of refugee-run organizations that engages primarily in lobbying activities, while its member organizations provide protection and settlement services. It was formed in 1984 in response to the "failures" of institutions like the British Refugee Council and UKIAS to "represent us, to fight for us" (speech by Refugee Forum Director, April 1991). Its aims include self-organization and self-determination: "helping refugees to help themselves" (Refugee Forum brochure). In 1990, according to its director, the Refugee Forum had 64 branches in the UK and Ireland. It remained, however, a loosely federated network operating on a small budget with only two full time employees.

The Refugee Forum advocates refugee empowerment and direct funding to refugee-led organizations. As such, it emphasizes a grassroots approach where refugees take charge of their own destiny, rather than rely on the established (often white-run) agencies. "Gone are the days when we sit with the begging bowl, waiting for institutionalized agencies with their missionary mentalities” (employee). It is closely linked to the African Refugee Housing Action Group, a charity established in 1979 to provide housing for African refugees based on self-help principles. The Refugee Forum also actively distances itself from the more established NGOs which it sees as a threat. Consequently, most of its members are not members of the British Refugee Council. Also, unlike the more established agencies, the Refugee Forum has publicly advocated helping individuals denied refugee status to "go underground" to avoid deportation.

\section{Conflict and Cooperation in the Domain}

In this section, we present four specific relationships between the organizations described above. In so doing, we describe surface dynamics characterized by both cooperation and conflict. By cooperation, we mean "socially contrived mechanisms for collective action" (Ring \& Van de Ven, 1994: 96); by conflict, we refer to "incompatible behaviour among parties whose interests differ” (Brown, 1983: 4). We will also probe beneath the surface to show that cooperation does not necessarily mean collaboration and that conflict can produce innovation.

\section{Cooperation}

In this section, we describe two cooperative relationships. We first show an example of cooperation between the Community Development Team and a variety of other organizations which, we argue, bears many of the hallmarks of a collaborative relationship. We then describe the relationship between the Refugee Legal Centre and the government, arguing that beneath apparent cooperation lies, not collaboration, but compliance.

\section{Collaboration - The Community Development Team}

The Community Development Team was set up to help refugee community organizations organize more effectively, develop management skills, raise funds, deal with granting agencies, etc. Its objectives are to empower refugee organizations by helping them to develop the confidence, knowledge, and skills needed to take action. In many respects, the Team reflects a broader change in the philosophy of the British Refugee Council to provide more scope for participation by refugee communities. 
Certainly the attitudes of the established agencies have changed; this one [the British Refugee Council] has changed. ... I think that the strategic planning exercise [on community development] here had an impact ... questioning the role of our services. Should we be doing this or should we be helping a community organization to do it? You have to introduce that questioning so you don't automatically assume that you've got to do it. Your role might be to help an refugee community organization to solve the problem (Team employee).

The Community Development Team does not have any formal authority to take on this role, in so far as the refugee community is concerned but it does possess resources - expertise, money, experience, etc., - that refugees do not. However, both the Team and the refugee community organizations operate in a situation where all resources are scarce: funding, expertise, and political pressure have to be obtained from a variety of different sources, making coordinated initiatives essential. In addition, the Team is unable to provide services to all the refugee community organizations that seek support. Therefore, by helping refugee community organizations to help themselves, the Team leverages these scarce resources.

The refugee community organizations voluntarily participate in these joint initiatives as, for example, in the Haringuay Refugee Consortium, which consists of four founding refugee community organizations of Eritreans, Iranians, Somalis, and Ugandans. Such organizations perceive that benefits derive from joint action, which would not accrue from working in isolation. In so doing, they accord the Community Development Team the legitimacy to speak on their behalf. Similarly, Team members set great store on full participation by refugees, according them the legitimacy of equal partners. These relationships appear to be consistent with the discussions of collaboration encountered in the literature. There have been many attempts to pool resources and share power in order to solve some of the many problems facing refugee community organizations.

The joint approach was a tactical move that we encouraged... to make composite applications which we thought have a better chance of competing for government funding. It also pools the experience that exists... the Home Office seems to be happier with joint applications. That's the feedback we got... We don't usually impose things on groups, we try to facilitate it... These joint initiatives are not at the cost of organizational identities. These refugees have their own organizations and only come together for common projects (Team employee).

In other words, the relationship between the Team and other organizations was one of mutual collaboration.

While this collaboration contributed to change in the domain, notably in the participation and empowerment of refugee community organizations, the domain parameters were not completely overhauled since the Team's role in empowering refugees reaffirmed its privileged position.

As far as letting go [of these refugee community organizations], it is a strange situation. I'm not trying to patronize them but they are like children at different stages of their life and, so, need different types of help. Some are older and should be more developed but [because of staff turnover] remain inexperienced (Team employee). 
Finally, it is important to note that one of the catalysts behind the British Refugee Council's creation of the Community Development Team was the Refugee Forum's confrontational and vocal support for refugee empowerment (see below).

\section{Compliance - The Refugee Legal Centre}

On the surface, interactions between the government and the Refugee Legal Centre appear to be highly cooperative. The Centre does launch challenges to government determination decisions but, regardless, civil servants in the Asylum Division clearly differentiated caseworkers in the Centre from private solicitors.

The relationship between us and the Refugee Legal Centre is one of respect. They don't work in an antagonistic sense, unlike some solicitors who are being paid by the client, who see it as much more confrontational, “you're wrong, I'm right” way. We do have a special relationship with the Centre which involves working with them to get the best result but without compromising either organization's standards or values. They tend to understand our problems a lot more and we understand theirs (civil servant).

The government also provided support for the Refugee Legal Centre, which it needed to aid in the processing of refugee applications under the new legislation.

We continue to liaise as closely as possible with the Refugee Legal Centre. We had a meeting recently about the new Bill and how to liaise [around procedures]. We are anxious to maintain the good relations we have there.... They do have anxieties and we are doing our best to work them through. It is in our interests to make the procedures work (civil servant).

This reliance of the government on the Refugee Legal Centre was, however, a short term phenomenon restricted primarily to the transition period until the new legislation and accompanying regulations were passed and implemented.

There's a political will at the moment to get us up and running. We've got a strong wind behind us and we're under no illusions that we've got to take advantage of the political will. It exists because they want their new asylum procedure in place and they can't do it without us... They can't disband us and get it done... but I shouldn't think it will last. I think we'll come down to earth about one year into the [new] Bill and they will start cutting our budget, squeezing and chopping (Centre employee). In fact, this period in which the Refugee Legal Centre possessed some leverage masked a far more enduring relationship in which the government was, by far, the more powerful player of the two.

For example, while, officially, the government had no role in the daily operations of the Refugee Legal Centre, in reality it had considerable influence. The Centre's separation from UKIAS and reconstitution as a separate organization had been instigated by the government.

Technically we [the Home Office] are entirely distinct [from the Refugee Legal Centre]: you have an independent organization. Where this falls down in the eyes of the public or of the pressure groups is that it does receive part of its funding from the government and critics say: "How can an organization that receives funding from the government be independent of the government?” We say that ... we have no say in how the organization runs. It's entirely up to them and their constitution how they carry out their work. That also falls down slightly when you consider that we gave 
them an ultimatum on how to reform themselves and later withdrew their funding on the basis that they didn't do it (civil servant).

However, the mandate of the Refugee Legal Centre was to provide independent legal advice to refugees. The nature of the close relationship between the Centre and the government did not passed unnoticed by other agencies, particularly when the government proposed giving it a monopoly over free legal representation. The British Refugee Council wrote to the Centre (then still part of UKIAS) asking it "not to agree to any expansion of its services at the expense of the abolition of legal aid” (Exile, 1991:1).

To counteract criticism, the government helped to ensure that the Refugee Legal Centre was "seen to be independent”; otherwise its “customers” might lose "faith” (civil servant).

I think, genuinely, ministers want to see the Centre work and we're not in the business of giving them a bad start.... I am only too well aware that there are significant pressures on the Centre from others in the refugee industry who are suspicious of their relationship with the Home Office and I'm not about to prejudice those relationships because that wouldn't be in anybody's interests (civil servant). In other words, cooperation occurred between these two organizations, but steps were taken to ensure that the full extent of this cooperation was hidden from other organizations in the domain.

This relationship does not constitute collaboration but compliance: the Refugee Legal Centre complied with the government because of the asymmetrical distribution of power. Employees of the Refugee Legal Centre had no illusions concerning the limits of their power.

We've come to the point where we've reached agreement on what we can and can't do. There's not much point in table pounding (Centre employee).

In effect, the Centre had been sufficiently socialized (see Warren et al., 1974) to know exactly how far it could go in challenging the government.

They undoubtedly do have reservations about aspects of the legislation but at this point it's not going to change. They accept that and try to make the best of it (civil servant).

This imbalance of power enabled the government to regulate the Refugee Legal Centre's actions to a great extent, preventing serious threats to its position from being made. For example, instead of agitating for major changes in the way the UK refugee domain was constituted, the Centre was more likely to submit to government demands, as can be seen from its stance on the new legislation.

We can participate in the public debate through the normal channels if it directly concerns our clients. My interpretation of the charity laws is they allow us to do that. I don't think we can initiate anything. I don't think we can march down the street and say: "The Refugee Legal Centre says down with the Home Secretary”. We can certainly participate in the debate on the Asylum Bill but we can't jump on every campaign for every detainee (Centre employee).

Accordingly, the Centre was not a major player in the opposition to the Government's new legislation.

There is a culture [at the Refugee Legal Centre] that does not favour resistance. If you're representing refugees you have to know where your bottom line is, but [the Centre] was nowhere in the current campaign about the Asylum Bill. You will not see the director on television against the Conservatives about what is happening (director of another agency). 
Instead, the Centre acted largely as an agent of the government in the latter's attempt to influence the domain. While this relationship undoubtedly had certain advantages — for example, in ensuring the smooth implementation of the new determination procedures - it is unlikely that this form of "collaboration" would produce much synergy. Significant innovation usually requires fundamental changes in conventional ways of thinking; and, in this case the Refugee Legal Centre was far more likely to replicate the government view than provide radical new alternatives.

In summary, the two cooperative relationships described here are quite different. The initiatives of the Community Development Team appear to be collaborative, if we reserve this term for a specific form of cooperation.

Collaboration operates on a model of shared power. In collaboration, problemsolving decisions are eventually taken by a group of stakeholders who have mutually authorized each other to reach a decision. Thus, power to define the problem and to propose a solution is effectively shared among the decision makers (Gray, 1989: 119).

Gray goes on to say that this does not mean that partners have to be equal in power; that powerholders have to relinquish it; nor that resources must be distributed equally. It does mean, however, that major inequities in power will probably undermine collaboration and, therefore, all parties need sufficient power to prevent other organizations from imposing solutions on them or other affected parties. Collaboration is thus a mutual engagement strategy in which all partners voluntarily participate. Compliance, on the other hand, is a very different form of cooperation, where power is neither shared nor is participation, strictly speaking, voluntary. Instead of the reciprocal relations we find in collaboration, the dominant partner uses its power to regulate weaker parties which have no choice but to cooperate.

\section{Conflict}

In this section, we examine conflict more closely. We first show how conflict between the Refugee Forum and other organizations emerged as a result of a new contender trying to enter and influence the domain. Finally, we depict apparent conflict between the British Refugee Council and the government which masks a far less adversarial relationship, which we call contestation.

\section{Contention - The Refugee Forum}

The Refugee Forum engaged in adversarial relations, not only with the government but also other agencies: it challenged the legal basis not only of the government's determination system, but of its entire immigration policy through its support of illegal aliens; it empowered refugees to run their own organizations; and it lobbied to cut established nongovernment organizations out of the funding relationship by channeling money directly to refugees. Consequently, it subjected most of the established white-run agencies to intense, public criticism.

The fact that all the money goes directly to the [established agencies] makes it very difficult for the [refugee community organizations] to cooperate with them... the British Refugee Council has the refugee associations by the short and curlies because it dispenses the funds. They are frightened to bite the hand that feeds them and if they do attack the Council, they will lose what little benefits they already have which is an extension of colonialism (Refugee Forum member).

These attitudes reflected a policy of “no cooperation”. 
I've never actually met the Forum but I've been on the receiving end of their letters that condemn everybody in sight. It's a bit wearing really. We've made our overtures, we've suggested meetings, we've suggested ways of co-existing when they were more of a force They have a very straightforward view: if you take the government's money, then you're the government's creature and that's it (British Refugee Council official).

The Refugee Forum considered that the British Refugee Council's reformist approach reinforced the government's control over the domain and the status quo, at the expense of refugees.

The British Refugee Council has been a disaster; when there is any parliamentary debate, the government can always say the British Refugee Council is dealing with the problem (Refugee Forum member).

To cooperate with the British Refugee Council, and other agencies like it, would undermine the very basis of the Refugee Forum's object of empowering refugees. Instead, it wanted to introduce new contenders - the refugees and, of course, itself — into the domain on an equal footing.

The response of the established agencies was one of marginalization.

The established groups try to marginalize the Refugee Forum. I don't really know why. I don't see them as a threat. Maybe they see the Forum's fairly straight forward way of expressing things as dangerous to the process of negotiations. I don't see why but they do see it as a problem and there were some fairly hairy rows (politician).

In this way, these groups hoped to "repel” the Refugee Forum's "extreme” demands (Warren et al., 1974) which, if acted on, would result in the transformation of the domain to the detriment of both government and NGOs. Despite these actions, the Forum did have an impact on the domain. It was highly successful in promoting refugee empowerment through its African Refugees Housing Action Group which, in 1988, became the first refugee-led housing association (among 2,300 housing associations) to be registered with the Housing Corporation (a $£ 2$ billion, government-funded agency that provides grants for non-profit housing). In 1992 it was the only refugee-led housing organization among the subset of 500 housing associations that received funding for property development. The Forum was also important in embarrassing established agencies, like the British Refugee Council, into sharing power with refugees, engaging in initiatives like the Community Development Team, and employing more refugees.

I tried to look at the Forum as an instrument to get the British Refugee Council running around.... the years of criticism made the Council nervous enough to make changes. A lot of change [in increasing refugee participation], we could say we owe to the Forum indirectly (Council employee - former refugee).

In other words, the Refugee Forum, despite minimal resources and dubious legitimacy in the eyes of established agencies, pushed its way into the domain and helped to shape the constitution of that domain.

The Refugee Forum is useful. It stems from the grass roots which results in an enormous commitment which is sometimes more effective than the British Refugee Council. It's more radical so its can't attract a lot of funding, while the Council has funding but is bureaucratic. Both have their limits. It's important to have the Forum because it challenges the other system. It provides a check and keeps them honest. 
Also, it sometimes identifies the real issues because it doesn't make the same assumptions that the Council does (refugee community organization representative).

In summary, the Refugee Forum introduced conflict into the domain as it engaged in a strategy of contention and the more established organizations tried to marginalize it. The conflict signaled the Forum's impact on the domain, an impact completely out of proportion to its authority and resources.

\section{Contestation - The British Refugee Council and the Government}

In many respects the British Refugee Council and Refugee Legal Centre are similar both are publicly-funded charities and subject to similar legal and financial constraints. The British Refugee Council was, however, more active in its opposition to government policies, particularly the new legislation. What distinguishes its relationship from that of the Refugee Legal Centre is not so much independence from the government, however, but a countervailing dependency on the refugee community organizations that comprised one-third of its membership. At the British Refugee Council, refugees were partners within a broader political forum, and not simply clients during a legal process as at the Refugee Legal Centre (Phillips \& Hardy, 1997). So, whereas, the Refugee Legal Centre did not purport to speak for the refugee community and, in any case, had little legitimacy to do so, the British Refugee Council sought such a role. These aspirations embedded it in a more complex web of power relationships, and necessitated a more active approach towards managing its legitimacy.

There is a different constituency here. We are responsible for asylum-seeking refugees and we are accountable to our membership... Our credibility is based on the support and backing of our membership. If we do not voice their concerns we will be dead and so the Home Office has to let us have our say (Council employee).

While the Council appeared to engage in an adversarial relationship with the government, it would be inaccurate to describe it in the same terms as the actions of the Refugee Forum. The latter represented "not merely a hard-fought contest to see who wins a particular chess game; [but] a threat to the game itself. It is one thing to fight hard to win a game; it is another thing to overturn the chess board" (Warren et al., 1974: 51). We refer to the Council's actions as an attempt to win the game, as opposed to overturning the chessboard. So, while the British Refugee Council lobbied actively, it was selective in the causes it supported. It concentrated on specific "winnable" issues (e.g., the proposal to end legal aid and to change the appeal system), thereby reaffirming the government's overall legislative framework. Nor could it afford to reject the government's agenda out of hand if it wanted to continue to participate in policy discussions.

Once a year we have an have an-off-the record discussion with civil servants. It takes place in a barrister's chambers with a glass of wine. Some people might see that as compromising with the enemy. But quite frankly, we have so many issues of concern which we try and influence the government on, we would be much less influential and persuasive if we simply treated them as the enemy (Council official). Certainly, the government had less control over the Council than the Refugee Legal Centre, and the Council did mount a vigorous campaign against certain government measures. But, by cooperating with the government, the British Refugee Council was effectively coopted: the government was willing to share the symbols of power by allowing the Council to participate in decision and policy making but, for practical purposes, the asymmetrical power relationship was maintained (see Selznick, 1966: 13-16). This enabled the government to "blunt" any threats 
posed by the Council by redefining them within the confines of the government's interests (Warren et al., 1974) as for example with its demand for a radically new approach to settlement. Our relationship with the Home Office? That's a tricky one. They go on funding us. We put in our submission [for funds] every three years and we more or less get it. But to the extent that we haven't got a national policy on settlement .... our influence has been marginal. ... By that criterion, we're a failure (Council employee).

The British Refugee Council's strategy of contestation allowed it to have some impact on the government, while managing its legitimacy in the eyes of other stakeholders to whom it was connected by other power relationships. The advantages of such a strategy revolve around being included in discussions by dominant stakeholders; while disadvantages relate to diluting proposals to make them more palatable to powerholders. So, while some innovation may occur, a radical overhaul of the domain is unlikely. The Council thus faced the classic dilemma of reformist organizations: in order to be taken seriously, it risked cooptation by the government.

In summary, our analysis uncovers two kinds of conflict. In contention, new entrants struggle to overturn existing domain parameters in order to make space for themselves and, in so doing, challenge dominant stakeholders. As new contenders, such organizations may not possess either formal authority or critical resources - if they did, they would probably already be active in the domain. They may, therefore, use discursive legitimacy to secure a voice (e.g., Elsbach \& Sutton, 1992; Phillips \& Hardy, 1997) which, in turn, may both depend upon, and lead to, a substantial overhaul of existing domain parameters. We suggest that the likely response to such a threat is marginalization, at least initially, when the new contender's legitimacy is most vulnerable and tenuous ( $c f$. Warren et al., 1974). If the new contender is successful in establishing its legitimacy, the definition of the problem that frames the domain will change and its place within it will become more secure. ${ }^{3}$ In the case of contestation, a stakeholder challenges existing powerholders but only within the limits of existing domain parameters, allowing it to maintain legitimacy in the eyes of quite different stakeholders. This strategy may produce some concessions, but it runs the risk of cooptation by powerholders.

\section{Conclusions}

As Hazen (1994: 398) points out, interorganizational relationships and networks are "vital to the work and community lives of most people". It is critical, therefore, that researchers deal with their complexity. This study of strategies of engagement is intended to move the discussion beyond the simple dichotomy of collaboration and conflict, and to focus attention on the complex dynamics of interorganizational domains. While more empirical investigation is required, we identify four strategies of engagement - collaboration, compliance, contention, contestation and describe four countervailing strategies, taken either to defend the domain from change or to influence the direction that change takes - reciprocal collaboration, regulation, marginalization and cooptation (table 1). Collaboration and contention appear to represent the greatest potential for synergy and innovation; contestation produces limited change; while compliance means that one organization simply acts as the instrument of the other.

\section{- TABLE 1 ABOUT HERE -}

By asking who has formal authority, who controls key resources, and who is able to discursively manage legitimacy, we can also identify various power dynamics. In the UK refugee domain, collaboration was associated with a dispersal of authority, resources and legitimacy among organizations, which suggests that collaboration may be easier when the various aspects of power are widely distributed. In the case of a significant power imbalance, compliance appears 
more likely, as in the case of the Refugee Legal Centre. It was highly dependent on the government regarding all aspects of power: the government had authority and resources; and the Centre depended on it to manage its legitimacy vis-à-vis other agencies. If power is not dispersed, collaboration may still be if power-holders exercise voluntary restraint but socialization - knowing that you are ultimately the weaker player — may lead less powerful organizations to comply with the actions they think their more powerful counterparts wish to see, even when they do not exercise their power. Contention is a viable strategy, even when actors do not possess formal authority or critical resources if they have some discursive legitimacy, as in the case of the Refugee Forum. Organizations cannot afford to ignore this aspect of power, even when they have authority and resources, as the British Refugee Council shows in its attempts to protect its right to speak on behalf of refugees.

As far as research on interorganizational interactions is concerned, we first suggest that power and politics are inseparable from the most fundamental processes of domain definition. The ability to participate in domain development and to define the problems that characterize it, depends either on having the power to make oneself heard or on the goodwill of powerful domain members to allow low-power participants to participate. We, however, saw no evidence of the latter in our fieldwork and suggest that research should consider more directly the role of power in the development of interorganizational domains, as well as the impact of the different aspects of power, which may complement and offset another.

Second, researchers must take care not to adopt the perspective of the most powerful stakeholders in judging the "success" of the collaboration. Given the importance of power in defining the problem and identifying stakeholders, it is all too easy to accept the stated goals of the collaboration, which means success is measured from the position of the powerful while equally legitimate outcomes, which favour low-power stakeholders, are excluded. Moreover, while collaboration can be highly productive in solving interorganizational problems, conflict also has a clear role in challenging existing frameworks and forcing domain change in directions considered by at least some members to be positive. Both aspects deserve equal attention since failure to recognize the importance of conflict leads to a preference for the status quo and an implicit adoption of the viewpoint of powerful stakeholders. Moreover, since early choices in the development of the domain can have a lasting effect as processes of institutionalization support their continuance, the work on domain development and strategies of engagement may benefit from a connection with the institutional theory literature (e.g., Phillips et al., 1996).

A number of practical implications also exist. As far as power-holders are concerned, there are two important points. First, while our research found collaboration only in a situation where power was already widely dispersed, in some circumstances high-power organizations may be willing to share power in order to achieve synergy and innovation (Hardy \& Phillips, forthcoming). Obviously, there are risks to such a strategy: for example, not being able to control the direction of change; the increased risk of an escalation of conflict as stakeholders acquire sufficient power to resist; and the greater time and effort required to manage such relationships. Consequently, research might address the issues associated with sharing power. Second, while dominant partners may seek the security of compliance from their partners, it is unlikely to produce innovative change. In a relationship based on regulation and compliance, the weaker organization simply acts as the tool of the former. This may be perfectly appropriate where issues of implementation are at stake, but it will be ineffective when more creative solutions are sought. 
Powerful organizations must therefore learn to identify the circumstances under which they could benefit from some relinquishing of control.

The lessons for members of less powerful organizations are equally important.

Collaboration is one way to derive benefit from changes to interorganizational domains. So, too, is conflict. But both require power. Often a lack of access to resources and formal authority make the prospects of either seem impossible. However, discursive legitimacy also provides a way to ensure recognition and participation (e.g., Elsbach \& Sutton, 1992). Such a strategy emphasizes the importance of managing meaning, communication and impression management in acquiring power. The example of the Refugee Forum shows how a relatively "powerless" organization can make a mark through this form of power (also see Phillips \& Hardy, 1997). 
Table 1

Strategies of Engagement in the UK Refugee System

\begin{tabular}{|c|c|c|c|c|}
\hline & $\begin{array}{l}\text { Community Development } \\
\text { Team/Refugee Organizations }\end{array}$ & $\begin{array}{l}\text { Refugee Legal Centre/ } \\
\text { Government }\end{array}$ & $\begin{array}{l}\text { Refugee Forum/ Agencies } \\
\text { and Government }\end{array}$ & $\begin{array}{l}\text { British Refugee Council/ } \\
\text { Government }\end{array}$ \\
\hline Surface dynamics & cooperation & cooperation & conflict & conflict \\
\hline Strategy of engagement & $\begin{array}{l}\text { collaboration by the } \\
\text { Community Development } \\
\text { Team }\end{array}$ & $\begin{array}{l}\text { compliance by the Refugee } \\
\text { Legal Centre }\end{array}$ & $\begin{array}{l}\text { contention by the Refugee } \\
\text { Forum }\end{array}$ & $\begin{array}{l}\text { contestation by the British } \\
\text { Refugee Council }\end{array}$ \\
\hline Counter-vailing strategy & $\begin{array}{l}\text { refugee organizations engage } \\
\text { in reciprocal collaboration }\end{array}$ & $\begin{array}{l}\text { regulation by government to } \\
\text { prevent threats from the } \\
\text { Refugee Legal Centre }\end{array}$ & $\begin{array}{l}\text { marginalization by other } \\
\text { organizations to repel threats } \\
\text { posed by the Refugee Forum }\end{array}$ & $\begin{array}{l}\text { co-optation by the } \\
\text { government to blunt threats } \\
\text { from the British Refugee } \\
\text { Council }\end{array}$ \\
\hline Power distribution & $\begin{array}{l}\text { no concentration of authority, } \\
\text { resources, or legitimacy: all } \\
\text { aspects of power are widely } \\
\text { distributed among } \\
\text { organizations }\end{array}$ & $\begin{array}{l}\text { the Refugee Legal Centre is } \\
\text { highly dependent on the } \\
\text { government regarding all } \\
\text { aspects of power: the } \\
\text { government has authority and } \\
\text { resources; also the Refugee } \\
\text { Legal Centre depends on the } \\
\text { government to manage its } \\
\text { legitimacy vis-à-vis other } \\
\text { agencies and refugees }\end{array}$ & $\begin{array}{l}\text { formal authority regarding } \\
\text { who has the right to speak for } \\
\text { refugees is unclear; other } \\
\text { agencies possess resources } \\
\text { but the Refugee Forum is not } \\
\text { dependent on them; the } \\
\text { Forum has some discursive } \\
\text { legitimacy to speak for } \\
\text { refugees because it is run by } \\
\text { refugees }\end{array}$ & $\begin{array}{l}\text { government possesses formal } \\
\text { authority and resources vis-à- } \\
\text { vis Council; Council has } \\
\text { some formal authority and } \\
\text { resources vis-à-vis refugee } \\
\text { organizations but has to } \\
\text { manage its legitimacy with } \\
\text { these groups to be allowed to } \\
\text { speak for them }\end{array}$ \\
\hline Change to domain & probable, consequential & unlikely, superficial & possible, significant & possible, limited \\
\hline
\end{tabular}




\section{References}

Altheide, D. L. (1988), "Mediating Cutbacks in Human Services: A Case Study in the Negotiated Order,” Sociological Quarterly, 29, 3, 339-35.

Astley, W. G. (1984), “Toward an Appreciation of Collective Strategy,” Academy of Management Review, 9, 3, 526-535.

Astley, W. G. and P. S. Sachdeva. (1984), "Structural Sources of Intraorganizational Power: A Theoretical Synthesis,” Academy of Management Review, 9, 1, 104-113.

Alter, C. (1990), “An Exploratory Study of Conflict and Coordination in Interorganizational Service Delivery Systems,” Academy of Management Journal, 33, 478-502.

Alter, C. and J. Hage (1993), Organizations Working Together, Newbury Park, CA: Sage.

Benard, C. (1986), "Politics and the Refugee Experience,” Political Science Quarterly, 101, 4, 617-636.

Benson, J.K. (1977), “The Interorganizational Network as a Political Economy,” Administrative Science Quarterly, 20: 229-249.

Benson, J.K. (1978), “Reply to Maines,” Sociological Quarterly, 19, 497-499.

Berger, P.L. and T. Luckmann (1966), The Social Construction of Reality, Garden City, NY: Doubleday.

Blumer, H. (1971), “Social Problems as Collective Behaviour,” Social Problems, 19, 298-306.

Bourdieu, P. (1993) Sociology in Question, London: Sage.

Bresser, R.K. (1988), “Matching Collective and Competitive Strategies,” Strategic Management Journal, 9, 375-385.

Bresser, R.K.. and J.E. Harl (1986), “Collective Strategy: Vice or Virtue?” Academy of Management Review, 11, 408-427.

Brown, L.D. (1983), Managing Conflict At Organizational Interfaces, Reading, MA: AddisonWesley.

Carney, M.G. (1987), “The Strategy and Structure of Collective Action,” Organization Studies, 8(4), 341-362.

Clegg, S. (1989), Frameworks of Power, London: Sage.

Cohen, R. (1994), Frontiers of Identity: The British and the Others, London: Longman.

Day, R. and J. Day (1977), “A Review of the Current State of Negotiated Order Theory: An Appreciation and a Critique,” Sociological Quarterly, 18, 126-142.

Day, R. and J. Day (1978), “Reply to Maines,” Sociological Quarterly, 19, 499-501.

Dutton, J.E. and R.B. Duncan (1987), “The Creation of Momentum for Change Through the Process of Strategic Issue Diagnosis,” Strategic Management Journal, 8, 279-295.

Eisenhardt, Kathleen M. (1989) “Building Theories from Case Study Research”, Academy of 
Management Review 14(3): 532-550.

Elsbach, K. D. and R.I. Sutton (1992), “Aquiring Organizational Legitimacy Through Illegitimate Actions: A Marriage of Insitutional and Impression Management Theories," The Academy of Management Journal, 35, 4, 699-738.

Exile (1991), Newsletter of the Refugee Council, \#51.

French, J.R.P. and B. Raven (1968), “The Bases of Social Power,” in D. Cartwright and A. Zander (eds.), Group Dynamics, New York: Harper and Row.

Frost, P.J. (1987), "Power, Politics and Influence," in F.M. Tablin, L.L. Putnam, K.H. Roberts, and L.W. Porter (eds.), Handbook of Organizational Communications: An Interdisciplinary Perspective, London: Sage.

Gray, B. (1985), “Conditions Facilitating Interorganizational Collaboration,” Human Relations, 38: 911-936.

Gray, B. (1989), Collaborating, San Francisco: Jossey-Bass.

Gray, B. and T.M. Hay (1986), "Political Limits to Interorganizational Consensus and Change," Journal of Applied Behavioral Science, 22, 95-112.

Gricar, B. and Brown, L.D. (1981), "Conflict, Power and Organization in a Changing Community”, Human Relations 34, 877-893.

Hall, P.M. and D.A. Spencer-Hall (1982), "The Social Conditions of the Negotiated Order," Urban Life, 11, 3, 328-349.

Hardy, C. (1985a), “The Nature of Unobtrusive Power,” Journal of Management Studies, 22, 4, 384-399.

Hardy, C. (1985b), Managing Organizational Closure, Aldershot, England: Gower Press.

Hardy, C. (1994), "Underorganized Interorganization Domains: The Case of Refugee Systems," Journal of Applied Behavioural Science,. 30, 3, 278-296.

Hardy, C. and S. Clegg (1996), "Some Dare Call It Power,” in C. Hardy and S. Clegg (eds.), Handbook of Organization Studies, London: Sage.

Harrigan, K.R. (1985), Strategies for Joint Ventures, Lexington, MA.: D.C. Heath/Lexington Books.

Hasenfeld, Y. and M.A. Chesler (1989), "Client Empowerment in the Human Services: Personal and Professional Agenda," Journal of Applied Behavioral Science, 25, 499-521.

Hazen, M.A. (1994), “A Radical Humanist Perspective of Interorganizational Relationships,” Human Relations, 47, 4, 393-415.

Hickson, D.J., C.R. Hinings, C.A. Lee, R.E. Schneck, and J.M. Pennings (1971), “A Strategic Contingencies Theory of Intraorganizational Power,” Administrative Science Quarterly, 16, 2, 216-229.

Home Office (1991/2), Annual Report, London: HMSO.

Kanter, R.M. (1990), “When Giants Learn Cooperative Strategies,” Planning Review, 18, 1, 15- 
25.

Knights, D., F. Murray, and H. Willmott (1993), ”Networking as Knowledge Work: A Study of Strategic Interorganizational Development in the Financial Services Industry”, Journal of Management Studies, 30, 6, 975-995.

Knoke, D. (1990), Organizing for Collective Action, Berlin: De Gruyter.

Laumann, E.O. and D. Knoke (1987), The Organizational State, Madison: University of Wisconsin Press.

Levy, J.A. (1982), “The Staging of Negotiations Between Hospice and Medical Institutions,” Urban Life, 11(3), pp. 293-311.

Lukes, S. (1974), Power: A Radical View, London: Macmillan.

Majika, M. (1991), Into the 1990s: The Needs of Refugee-Based Organizations and Refugees in Britain, Oxford: Refugee Studies Program.

McCann, J.E. (1983), “Design Guidelines for Social Problem-Solving Interventions,” Journal of Applied Behavioral Science, 19, 177-189.

McGuire, J.B. (1988), “A Dialectical Analysis of Interorganizational Networks,” Journal of Management, 14, 109-124.

Mumby, D. and C. Stohl (1991), "Power and Discourse in Organization Studies: Absence and the Dialectic of Control,” Discourse and Society, 2, 3, 313-332.

Nathan, M.L. and Mitroff, I.I. (1991), "The Use of Negotiated Order Theory as a Tool for the Analysis and Development of an Interorganizational Field,” Journal of Applied Behavioral Science, 27, 163-180.

O’Toole, R. and A.W. O’Toole (1981), “Negotiating Interorganizational Orders,” Sociological Quarterly, 22, 1, 29-41.

Parker, I. (1992), Discourse Dynamics. London: Routledge.

Pettigrew, A.M. (1973), The Politics of Organizational Decision Making, London, England: Tavistock.

Pettigrew, A.M. (1979), “On studying Organizational Cultures,” Administrative Science Quarterly, 24, 570-81.

Pfeffer, J. (1981), Power in Organizations, Marshfield, MA: Pitman.

Pfeffer, J. and G.R. Salancik (1978), The External Control of Organizations, New York: Harper and Row.

Phillips, N. and J. Brown. (1993), “Analyzing Communication In and Around Organizations: A Critical Hermeneutic Approach,” The Academy of Management Journal, 36(6): 1547-1576.

Phillips, N. and C. Hardy (1997), “Managing Multiple Identities: Discourse, Legitimacy and Resources in the UK Refugee System,” Organization, forthcoming.

Phillips, N., T. Lawrence, and C. Hardy (1996), Understanding Collaboration in Context: The Dynamic of Institutional Fields and Interorganizational Domains, Unpublished working 
paper, McGill University. (Paper available from authors.)

Ring, P.S. and A. Van de Ven (1994), "Developmental Processes of Cooperative Interorganizational Relationships,” Academy of Management Review, 19, 90-118.

Rogers, D.L. and D.A. Whetten (1982), Interorganizational Coordination: Theory, Research and Implementation, Ames, Iowa: Iowa State University Press.

Rose, S.M. and B.L. Black (1985), Advocacy and Empowerment: Mental Health Care in the Community, Boston: Routledge and Kegan Paul.

Salinas, M., D. Pritchard, and A. Kibedi (1987), Refugee-Based Organizations: Their Function and Importance for the Refugee in Britain, Oxford: Refugee Studies Program.

Selznick, P. (1966), TVA and the Grass Roots, Berkeley: University of California Press (second edition).

Strauss, A., L. Schatzman, D. Ehrlich, R. Bucher, and M. Sabshin (1963), "The Hospital and It's Negotiated Order”, in E. Freidson (ed.), The Hospital in Modern Society, 147-169, London: Collier-Macmillan.

Smircich, L. \& Morgan, G. (1982), "Leadership: The Management of Meaning”, Journal of Applied Behavioral Science, 18(3), 257-273.

Trist, E. (1983), "Referent Organizations and the Development of Interorganizational Domains," Human Relations, 36, 269-284.

Thompson, J.B. (1990), Ideology and Modern Culture, Stanford, CA: Stanford University Press.

Waddock, S.A. (1989), “Understanding Social Partnerships: An Evolutionary Model of Partnership Organizations,” Administration and Society, 21, 78-100.

Warren, R., S. Rose, and A. Bergunder (1974), The Structure of Urban Reform, Lexington, MA: DC Heath.

Westley, F. (1995), "Governing Design: The Management of Social Systems and Ecosystems Management," in L. Gunderson, C.S. Holling and S. Light (eds.), Barriers and Bridges to the Renewal of Ecosystems and Institutions, Ithaca: Columbia University Press.

Westley, F. and H. Vredenburg, H. (1991), "Strategic Bridging: The Collaboration Between Environmentalists and Business in the Marketing of Green Products," Journal of Applied Behavioral Science, 27, 65-90. 


\section{Endnotes}

${ }^{1}$ Data on the UK refugee system was collected through interviews with civil servants, politicians, NGO officials, and refugees that took place between 1990 and 1993. In addition, documentary and archival evidence was collected, including published material in the form of government statistics, annual reports, and minutes from annual meetings, Hansard reports of parliamentary speeches and newspaper articles. Individual interviewees also provided internal reports, memos, etc. The situation described in this paper refers to refugee determination and settlement in the early 1990s.

${ }^{2}$ The terminology used here is as follows. An asylum-seeker or refugee claimant is an individual seeking asylum. Refugee refers to an individual granted asylum whether as a refugee or some other category. Determination refers to the process whereby an individual's status is ascertained. Nongovernment organizations and lawyers who represent and advise claimants concerning their rights in this process are known as protection agencies. Settlement refers to the services provided to refugees to help them settle in their new country, including training, housing and other support services. Refugee community organizations are small, usually ethnic-based refugee-led organizations that provide both protection and settlement services to refugees.

${ }^{3}$ We observe similar situations in the case of the environment, where organizations that once had no role in interorganizational decision making are now routinely and consulted; and in the case of the First Nations in Canada, who were excluded from constitutional talks in 1987 but, as their legitimacy was established, became part of discussions in 1992. 


\section{University Library}

\section{- M M N E R VA A gateway to Melbourne's research publications}

Minerva Access is the Institutional Repository of The University of Melbourne

Author/s:

Hardy, C;Phillips, N

Title:

Strategies of engagement: Lessons from the critical examination of collaboration and conflict in an interorganizational domain

Date:

1998-03-01

Citation:

Hardy, C. \& Phillips, N. (1998). Strategies of engagement: Lessons from the critical examination of collaboration and conflict in an interorganizational domain. ORGANIZATION SCIENCE, 9 (2), pp.217-230. https://doi.org/10.1287/orsc.9.2.217.

Persistent Link:

http://hdl.handle.net/11343/116091 